\title{
ABDALLAH HAMMADI: \\ ÉTICA Y ESTÉTICA NEOANDALUSÍ
}

IsAaC DONOSO

Universidad de Alicante

\section{ARGELIA, ESPAÑA Y LA PASIÓN POR AL-ANDALUS}

Existen personas fieles con su destino que son capaces de asumir en su propio cometido vital la culminación, el esfuerzo por llevar a cabo un fin que el tiempo impone. Los argelinos nacidos bajo la colonización francesa tuvieron que armarse física e intelectualmente para forjar una revolución, a sabiendas de que muchos perderían la vida en el intento. Los argelinos nacidos tras la Revolución no se encontraron ante ellos con un panorama más alentador, pues tenían que construir un país desde los cimientos, cimientos poco fiables tras una intervención colonial culturalmente alienante y socialmente agresiva. $\mathrm{Y}$ en ríos revueltos siempre pueden aparecer mensajes fáciles, salvapatrias, oportunistas o demagogos que establezcan un discurso intelectual interesado y orientado. De ahí la máxima exigencia que la sociedad que ha sido capaz de armar una revolución, revolución también en términos culturales, imponga a las mentes que deben trabajar por construir la identidad moderna de una naciente nación.

Argelia debía mirar al futuro pero, para hacerlo, debía levantar el edificio sobre cimientos sólidos, los cimientos que se fraguan cuando se asume el hecho y devenir históricos. Y éstas son las dos claves del imperativo ético que un intelectual de un país no alineado en los años setenta debía asumir: trabajo e historia o, en otras palabras, el incesante esfuerzo por reconstruir una narrativa histórica y rigurosa. $Y$, de nuevo, suele ser éste el esce- 
nario idóneo para formular un discurso postcolonial que quiera rendir cuentas con el colonialismo, de suerte que el discurso del colonizado acabe siendo tan interesado como el discurso del colonizador. No hay pensamiento que lo refleja más cabalmente que las máximas del escritor filipino José Rizal expuestas en su segunda novela El Filibusterismo (1891):

¿A qué darles libertad? ¡Con España y sin España serían siempre los mismos, y acaso, acaso peores! ¿A qué la independencia si los esclavos de hoy serán los tiranos de mañana? ¡Y lo serán sin duda porque ama la tiranía quien se somete a ella! ${ }^{1}$

De ahí la exigencia, también histórica, que la sociedad debe de tributar a aquellas mentes que se han dedicado, con honestidad intelectual y trabajo riguroso, a enaltecer la libertad que el conocimiento otorga. Creemos que éste es el caso de Abdallah Hammadi. Y lo es no sólo para el caso de Argelia, para una Argelia postcolonial que necesitaba profesores universitarios, arabistas, filólogos, pensadores, críticos literarios, poetas, novelistas, traductores e historiadores. Todo esto ha sido Abdallah Hammadi para Argelia. Sino también, como decimos, para el caso de España, para una España tardofranquista, cerrada al mundo, pero que necesitaba exportar la inmensa cultura que poseía en frascos de alcanfor. Y entre la exigencia por redactar una nueva historia de Argelia, y el gusto por estudiar la cultura española, apareció el punto de encuentro inevitable: al-Andalus como pasado de ambos, y futuro necesario:

¿Qué diré del al-Andalus de mis entrañas y de las primeras citas entre naranjos y olivos? ¿Conserva acaso el perfume de

${ }^{1}$ José Rizal, El Filibusterismo, edición crítica de Isaac Donoso, traducción filipina de Virgilio Almario, prólogo de Floro Quibuyen, Quezon City, Vibal Foundation (en prensa), cap. xxxix. 
la espada de Táriq, o la locura del Parnaso adornado de hojas de laurel y espectros de alas tornasoladas que acarician lo imposible? ¿Es quizás al-Andalus las norias asomadas a los miradores del Tajo y los arcaduces cuyo incesante regar llega a los oídos de los sedientos y de los que caminan en la certidumbre? Es el reino de los enamorados que escuchan el susurro de las tardes escondidas tras las murallas que despuntan más allá de la majestad y cuyo telón cae sobre las torres de Sevilla mientras se dispone a desdoblar los pañuelos de Rumaykiyya cuando celebra la estación de los almendros en flor y de la nieve que llega por los miradores del norte portadores del tañido de las campanas ${ }^{2}$.

Al-Andalus es un tópico manido, un concepto literario recurrente, un escapismo muchas veces fácil para el literato árabe ${ }^{3}$. Pero no creemos que sea éste el caso. Abdallah Hammadi no es un oriental, conoce perfectamente la sociedad y cultura españolas y, más que literato, se ha formado como filólogo e investigador con la mejor escuela de arabistas españoles. Lo andalusí no constituye un adorno, ni en su producción poética ni, indudablemente, en su labor científica. Pero para el Abdallah Hammadi que compone tan bellamente, tanto en español como en árabe, en esta introducción a su libro Al-Andalus entre el sueño y la realidad. Antología de la poesía española andaluza contemporánea (2008), al-Andalus va más allá del mito, para transformarse en una realidad rescatada del olvido.

$\mathrm{El}$ intelectual argelino debe guiarse por una ética, pero la

2 Abdallah Hammadi, “Al-Andalus entre el sueño y la realidad”, en $A n$ nales du Laboratoire de Traduction, Constantina, Universidad de Constantina, núm. 3, p. 7 (versión española del texto aparecido en Al-Andalus bayna alhulm wa-l-haqùqa. Anțūlü̂yìyā min al-šir al-isbānī al-andalusì al-mu'āṣar, Argel, Dār Bahā’ al-Dīn, 2008, p. 9).

3 Sigue siendo perfectamente válida la referencia de Pedro Martínez Montávez, Al-Andalus, España, en la literatura árabe contemporánea, Madrid, Mapfre, 1992. 
culminación debe de ser estética, o no será, o será otra cosa, será realismo proletario, compromiso mal entendido, cuentas pendientes con el colonizador, populismo, demagogia o, simplemente, malversación cultural. La construcción cultural no puede levantarse sobre el odio y el revanchismo, más bien al contrario, y así lo plantea Hammadi en la pregunta 3 de su encuesta a los poetas andaluces, la cual encabeza con el título «Llamada fraternal a los poetas andalusíes de hoy»:

$3^{\circ}$ En la época árabe de Al-Andalus, según narran los cronistas, la poesía llegó a ser algo como el pan de cada día, incluso entre campesinos y labradores; y así puntualiza el cronista Ibn Bassām en su Dajira que la poesía llegó a impregnarlo todo hasta el punto que si pides a un labrador, que va tras su arado, que te componga una poesía, te lo hace en el acto. ¿A qué se debe toda esta riqueza poética? ¿Cuál es el secreto en todo esto? Tal vez Al-Andalus por ser tierra de tanto encuentro y cruce cultural llegó a ser inspiradora como la mujer imposible que tanto cantan los poetas a través de la historia? ${ }^{4}$

La ética hammadiana yace en responder a las exigencias argelinas no con un mensaje revanchista, dogmático o politizado, sino con un mensaje cultural, además de la más alta cultura, la cultura andalusí, de la cual Argelia también fue heredera. Y para llegar a ese reducto de la memoria civilizacional, establece como primer paso la "conversión al olvido", casi a modo de intuición mística: Andalus al-ašrwāq / أندلس الاشواق lo llama Hammadi, "Deseo de al-Andalus", con un concepto que recuerda al Tarŷumān al-ašrwāq / نرجـمان الأشواق , "Intérprete de los deseos" del místico

${ }^{4}$ Abdallah Hammadi, "Al-Andalus entre el sueño y la realidad", loc. cit., p. 17 (versión española del texto aparecido en Al-Andalus bayna al-hulm wal-haqiqua, loc. cit., p. 35). 
andalusí Ibn 'Arabī:
¡El temporal de la soledad muerde el vacío de tu horizonte!
$\mathrm{Y}$ una frescura de arco iris cae en pesadillas en tu lecho nocturno.
¡Lejos de viento quedó tu arenal sin navío!
¡Qué sorbo de aroma te alivia!
¡Qué grito fantasmal se ve urgir entre las ventanas de tu abismo! ${ }^{5}$

Hammadi en este sentido no inventa el sentimiento, no ya de nostalgia, sino de encontrar en al-Andalus respuestas a la identidad árabe, en el recuerdo, en la memoria, en el olvido. Consecuentemente cita a Adonis:

Por eso dice Adonis en "La música del pez azul (p. 394)": "Me resulta difícil explicar mi relación con al-Andalus. Está ligada al recuerdo, al deseo, a los sueños. No sé qué veo en al-Andalus, pero es algo que no puedo transmitir. ¿Se ha convertido por eso en una segunda lengua? ¿En un texto original y global? ¿Habita en mi imaginación, formando un todo con ella? He hablado con al-Andalus como si se tratara de alguien ausente y presente a la vez a quien comunicar mis pensamientos. Y ella se limita a ser fuente de inspiración ${ }^{6}$.

Lo que sí inventa Hammadi, y lo hace no sólo suyo, sino también parte de argelinos y españoles, es esa recuperación de

${ }^{5}$ Abdallah Hammadi, Converso con el olvido, Constantina, Universidad de Constantina, 2003, p. 1.

${ }^{6}$ Abdallah Hammadi, "Al-Andalus entre el sueño y la realidad", loc. cit., p. 8. 
al-Andalus en clave moderna y viva, es decir, no sólo como ejercicio de arqueología filológica y crítica textual, sino también como "realismo mágico". Y para ello seguramente se haya servido de su conocimiento, excepcional dentro del mundo árabe, de la obra de Gabriel García Márquez y la literatura hispano-americana. Al-Andalus tiene que ser un lugar de la memoria, Macondo árabe que se recupere del olvido, para vivirse, en su cultura y su legado, en su sensibilidad y gusto estético. Hammadi es un intelectual, nada hay de nostalgia ni de reivindicación política en la idea de al-Andalus, idea usada y abusada por propios y extraños. La idea hammadiana es exclusivamente cultural, vivencial, para que la estética del gusto andalusí sea herramienta para la construcción moderna de argelinos y españoles. Y Estética es todo, el todo ontológico:

En virtud de lo anterior, la Estética ha de comprenderse en tanto que orden mayor de la universalidad cualitativa y unidad preferente de la universalidad, trabada en el todo de las conexiones, el Espíritu, entre el hombre, la naturaleza y la vida. La Estética se resuelve como una ontología; es una ontología cualitativa de la unidad y el todo. Una ontología dinámica que históricamente se mueve. La Estética se resuelve como la ontología; filosofía primera, que está en el centro ${ }^{7}$.

Tras la ética investigadora, académica y científica, Hammadi obra, escribe y poetiza, construye literatura que pueda funcionar en la definición ontológica del ser argelino, del ser español, de esa nueva poesía andaluza que llama al-šir al-isbāni al-andalusī / La idea es dar forma académica y literaria a una nueva estética andalusí/andaluza/española, desde la

\footnotetext{
${ }^{7}$ Pedro Aullón de Haro, "Estética y objeto estético", en Caracteres Literarios, 2001, p. 13.
} 
herencia argelina, al tiempo que responder a la necesidad ontológica de definir, también, una estética argelina con la cual afrontar los desafíos de la modernidad. De ahí que Hammadi escriba en español, pues el español le permite ser el eslabón de un continuum que sobrevive en la memoria, aquella historia que nació en la Granada de Ibn al-Jatịib, siguió desterrada en la Argel de Cervantes, y debe continuar en la Constantina de Hammadi:

\author{
Por tu trágica sin venganza \\ renunciaré a mi Sinhaya. \\ Por tus rosas del recuerdo \\ encarnaré a Abu-1-Hayyay. \\ Por tu sorda lejanía \\ resucitaré a Ibn al-Jatib. \\ Por tus torres brumosas \\ edificaré mis casidas. \\ Con azucenas y zureo levantaré tu al-mibrab. \\ Con mi sudor de zinati \\ y mi yegua berberisca \\ alcanzaré tu Ben Omaya. \\ Regaré tus arriates, tu ámbar de Oriente \\ con el treno de mi laúd de mirto. \\ Por el vino y el copero. \\ Por el mancebo y la Zumaya. \\ Por Badis y el Bermejo. \\ Te haré ofrenda, mi Constantina ${ }^{8}$.
}

De ahí que sea pertinente en la obra de Abdallah Hammadi establecer el concepto «neoandalusí» para el proyecto intelectual y literario que encarna. Frente a un colonialismo culturalmente agresivo que había alienado al argelino con su pasado mediante la sustitución lingüística y la diglosia, Hammadi encuentra en la lengua española una liberación y, sobre todo, una herramienta

\footnotetext{
${ }^{8}$ Abdallah Hammadi, Converso con el olvido, ob. cit., p. 31.
} 
con la que explorar, intuitivamente, al modo sufí, las estructuras cognitivas del ser y, en última instancia, comunicarse con el olvido.

Siempre navegando por el camino:

desde los confines del Hoggar, un vasto

pasto

de arenal me guía;

¡lamiendo el céfiro de un latido sereno!

Un río de cristal se vierte

hacia el infinito

En la otra orilla, dos siluetas de verde

clamor suplican el horizonte 9 .

Hammadi plantea la conversión, la extinción, el abandono al lugar más remoto del ser, donde habita el olvido. Cualquier lector español seguro que ya sabe de lo que Hammadi está hablando:

Donde habite el olvido,

En los vastos jardines sin aurora;

Donde yo sólo sea

Memoria de una piedra sepultada entre ortigas

Sobre la cual el viento escapa a sus insomnios.

Donde mi nombre deje

Al cuerpo que designa en brazos de los siglos,

Donde el deseo no exista.

Así comienza el famosísimo poema de Luis Cernuda "Donde habite el olvido", poeta andaluz que expresa la extinción del ser en el olvido. Hammadi realiza una operación similar, la de convertirse al olvido, allí donde al-Andalus es mito, para, una

\footnotetext{
${ }^{9}$ Ibid., p. 47.
} 
vez extinguido el deseo, devolverlo de hecho y por derecho a la realidad:

\author{
¡Ay hermano Federico! \\ Que he venido para sacudir de tu frente \\ el polvo del olvido para sembrar sobre tu losa \\ una flor \\ cuyo nombre es al-Andalus. \\ Hermano, \\ que hoy vengo para llevarme la ceniza de tus \\ huesos \\ y quemarla como incienso en el templo de \\ nuestra liberación sagrada ${ }^{10}$.
}

Hablamos por lo tanto de ética argelina y estética neoandalusí, del reto con el que el destino desafiaba a los intelectuales argelinos a partir de los años setenta, y de la solución andalusí, andaluza y española que logró encontrar Hammadi para responder al dilema. Era necesario encontrar una comunión con los escritores españoles contemporáneos, sobre todo con los andaluces. Al mismo tiempo era imperativo aprender la lengua de Cervantes, y cultivar el argelinismo en clave hispánica, o hispanoárabe. Suponía a la vez una liberación del yugo colonial, como una reivindicación de la memoria, la historia y el legado árabe en el Mediterráneo occidental. Converso con el olvido no es tan sólo un breve libro de poesías, ilocalizable, manuscrito perdido como la legendaria obra de Cide Hamete Benengeli. Converso con el olvido es sobre todo una obra fundacional dentro de las Letras Argelinas, pues no hay mayor rigor y coherencia en la historia de cualquier literatura que la continuidad, y en este caso la continuidad se logra con el símbolo argelino de uno de los mayores genios de la literatura universal:

\footnotetext{
${ }^{10}$ Ibid., p. 7.
} 


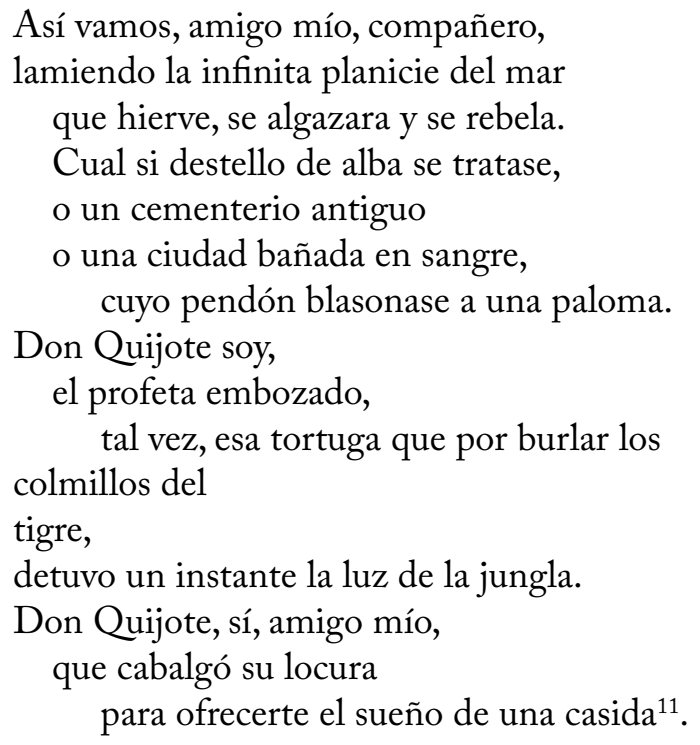

Converso con el olvido da por lo tanto continuidad a una literatura hispanoargelina que nunca fue pero siempre ha estado presente, como aquellos moriscos exiliados, como aquellos cautivos depauperados. Al-Andalus y España han estado siempre presentes en Argelia, pero sus voces se han relegado al olvido. Abdallah Hammadi regresa al olvido para rescatar esa voz, para convertirse en esa voz, de morisco nuevo, de neoandalusí, como si el continuum histórico nunca se hubiera detenido.

Lo curioso de esta historia, y lo trágico, es que el esfuerzo de Abdallah Hammadi acabó igualmente en el olvido, como toda esa literatura morisca, clandestina y cifrada. Converso con el olvido es intrascendental para la historia de las literaturas hispánicas, no ha sido valorado como obra fundacional de una "literatura hispanoargelina contemporánea”, y ha pasado desapercibida tanto para la crítica como para la historia literaria. Peor aún,

${ }^{11}$ Ibid., p. 40. 
Abdallah Hammadi parece no haber recibido el reconocimiento que merece por parte del Hispanismo y el Arabismo español.

Este pequeño trabajo, incluido en un número homenaje dedicado a su figura y obra en Revista Argelina. Revista semestral de Estudios Argelinos, pretende ser una guía para adentrarse en la obra de Abdallah Hammadi, y revalorizar su contribución a la literatura argelina, la literatura hispánica, la historia y crítica literarias, la filología, el Arabismo y el Hispanismo.

\section{BIBLIOGRAFÍA HAMMADIANA}

Se relacionan a continuación las principales obras de Abdallah Hammadi, tanto en lengua árabe como española, por orden cronológico y divididas entre obras literarias y académicas. Se indica entre corchetes los títulos en español de las obras en árabe:

\section{OBRAS LITERARIAS:}

1) Converso con el olvido, Madrid, La Buhardilla, 1979 (2a edición: Constantina, Universidad de Constantina, 2003).

2) Al-biŷra ilà mudun al-ŷunūb [Emigración hacia las ciudades del sur], Argel, SNED, 1981.

3) Qașāid gaŷariyya [Poemas gitanos], Argel, ENAL, 1983.

4) Tahazzaba al-išq yā Laylà [Oh Leila, la pasión sobreviene], Constantina, al-Ba'aț, 1985.

5) Al-Barzaj wa-l-Sikkin [Umbral y Cuchillo], Damasco, Ministerio Sirio de Cultura, 1998 (2a edición Argel, Dār Huma, 2002; $3^{a}$ edición Constantina, Universidad de Constantina, 
2004; 4a edición Constantina, Dār al-Alma'iyya, 2010; y 5a edición Constantina, Casa Numidia, 2016).

6) Tafunasit, novela, Argel, ENAL, 2006.

7) Unțq 'an al-hawà [Háblanos desde las vísceras], Constantina, Dār al-Alma'iyya, 2011.

OBRAS ACADÉMICAS:

1) Gābriyāl Gārsiyā Mārkìz. Rä̀id al-wāqa ìyya al-sahriyya [Gabriel García Márquez. Pionero del Realismo Mágico], Argel, ENAL, 1983.

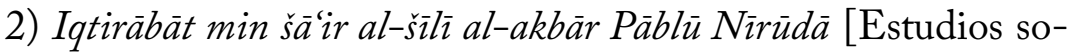
bre el gran poeta chileno Pablo Neruda], Argel \& Túnez, SNED \& MTED, 1985.

3) Madjal ilà al-šìr al-isbānī al-mu'ạșar [Introducción a la poesía española contemporánea], Argel, ENAL, 1985.

4) Dirāsāt fì al-adab al-magribì al-qadìm [Estudios sobre la antigua literatura magrebí], Constantina, al-Ba'ath, 1986.

5) Al-Müriskyūn wa muhākim al-taftì̌ fì al-Andalus. 1492-1616 [Los moriscos y la Inquisición española. 1492-1616], Argel \& Túnez, SNED \& MTED, 1989.

6) Masālāàt fì al-fikr wa-l-adab [Preguntas sobre pensamiento y literatura], Argel, Departamento de publicaciones universitarias, 1994.

7) Al-haraka al-țalābiyya al-ŷazāiriyya. 1871-1962 [Movimiento de los Estudiantes Argelinos. 1871-1962, Argel, Museo Nacional de los Mártires, 1994. 
8) Tuhfat al-Ijwān fì tabrīm al-dujān li-'Abd al-Qūdir al-Rāšidì al-Qusanțin̄i, edición de Abdallah Hammadi, Beirut, Dār algarb al-islamī, 1997.

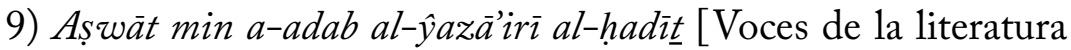
argelina contemporánea], Constantina, Universidad de Constantina, 2000.

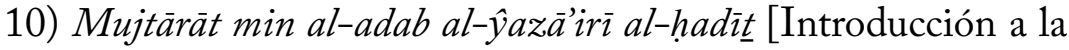
poesía argelina contemporánea], Kuwait, Fundación Babtain, 2001.

11) Al-šíriyya al-'arabiyya bayna al-ittibā'wa-l-ibtidād [La poética árabe entre el conservadurismo y la innovación], Constantina, Universidad de Constantina, 2001.

12) Andalusiyyāt. Garnāta wa-l-šir [Andalusíes. Granada y la poesía], Constantina, al-Ba'at, 2004.

13) La poesia en el reino nazari de Granada. 1232-1492, Kuwait, Fundación Babtain, 2004.

14) Rịhla Muhammad al-Zāhì al-Millī min Pārìs ilà Qusanțina [Viaje de Muḥammad al-Zāhī al-Millī de París a Constantina], edición de Abdallah Hammadi, Constantina, al-Ba'aț, 2004.

15) Fukāhāt al-asmār wa madhabāt al-ajbār wa-1-ašār li-Ibn Hudayl [Diversiones nocturnas y noticias de escuelas poéticas de Ibn Hudayl de Granada], Kuwait, Fundación Babtain, 2004.

16) Dīwān Ahmad al-Gwālmī [Obra poética del poeta argelino Aḥmad al-Gwālmī], edición de Abdallah Hammadi, Argel, Ministerio argelino de la cultura, 2005.

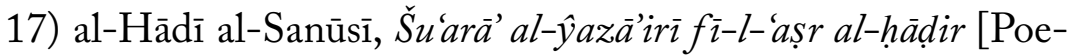
tas argelinos de nuestros días], edición moderna de Abdallah 
Hammadi Constantina, Dār Bahāa al-Dīn li-1-Našr wa-1-Taw$\mathrm{z}^{\prime}{ }^{\prime}, 2007,2$ vols.

18) Al-Andalus bayna al-hulm wa-l-ḩaqiqa. Anțūlūŷìyā min alšîr al-isbānì al-andalusī al-mu'āsar [Al-Andalus entre el sueño y la realidad. Antología de la poesía española andaluza contemporánea], Argel, Dār Bahā’ al-Dīn, 2008.

19) Sìra al-Muȳāhid Jayr al-Dīn Barbarūs fì al-ŶYazāìr [Vida de Jeireddín Barbarroja en Argelia], Argel, Dār al-Qaṣba, 2009.

20) Al-Ŷazä̀ir al-faransiyya min munzūr ahd al-ahālì li-mu'alifibi al-šarîf Ibn Habìlis [La Argelia francesa vista por un indígena, de Ben Hbiles], Argel, Dār Bahā’al-Dīn, 2009.

21) Târìj balad Qusanțina li Ibn al-Ațār [Historia de la ciudad de Constantina de Ibn al-'Ațār], Argel, Ministerio de Cultura, 2011.

22) Al-durr al-munazzim fì al-mawlud al-nabuwwī al-mu'ażim li-l-imām al-'Azafī [Perla ordenada del natalicio del más grande de los profetas], Amán, Dār al-Yāzūrī, 2015.

23) Malhama tārìj Qusanțina [Epopeya de la historia de Constantina], Argel, 2016. 


\section{APÉNDICE ICONOGRÁFICO}

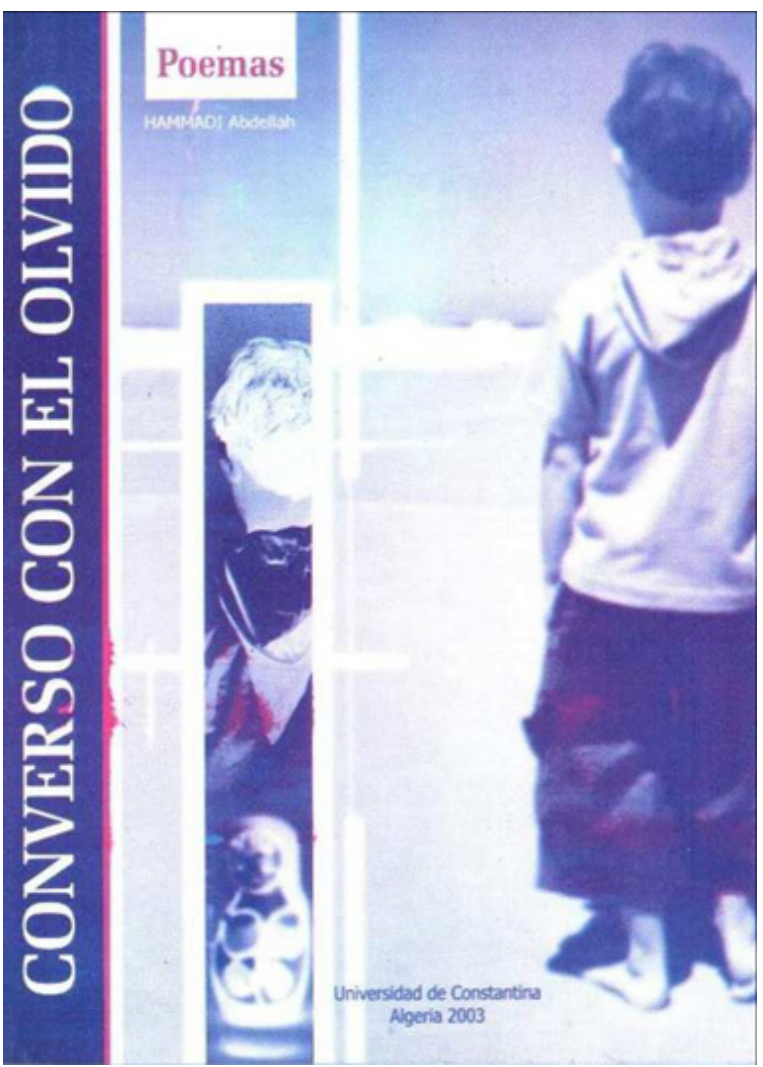


حمَاري عَبدانه
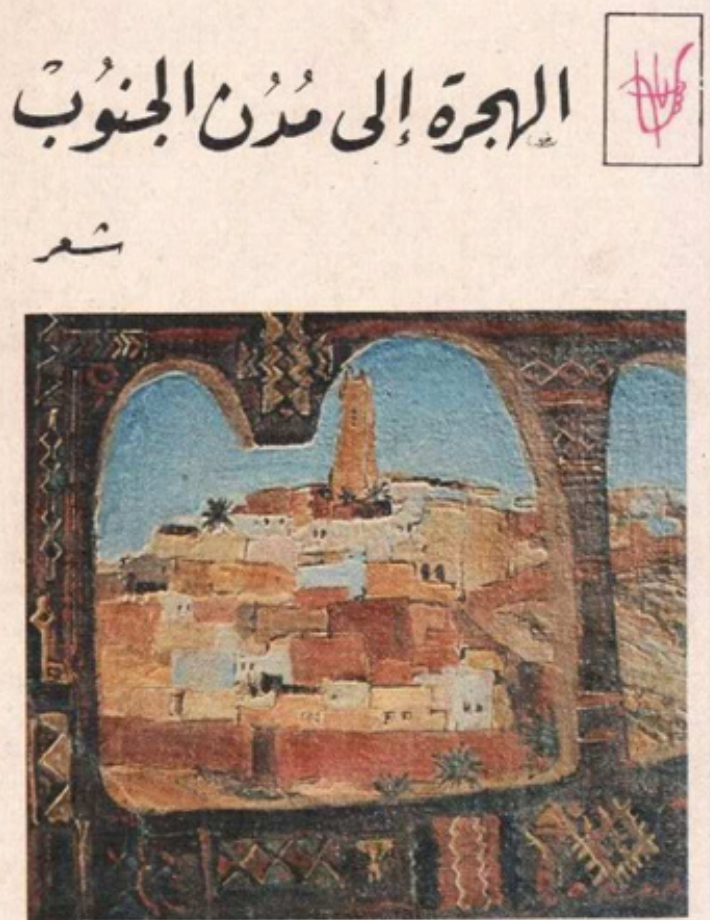

Ap 


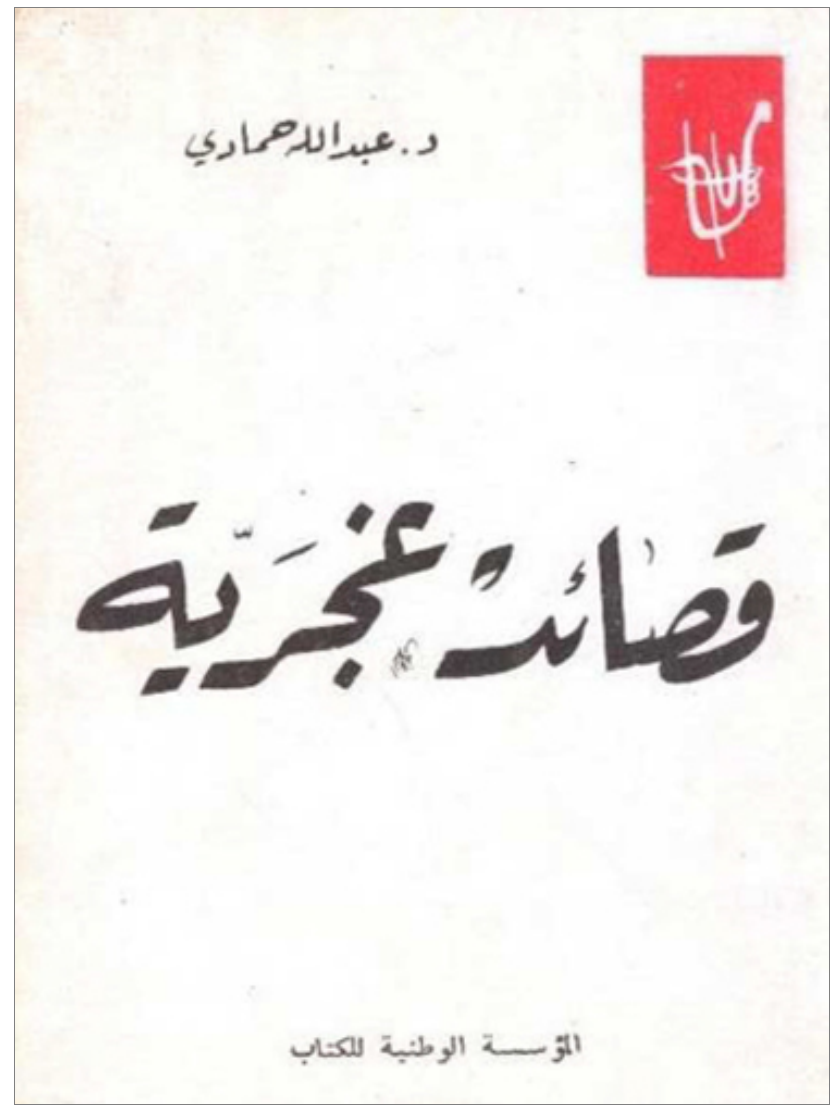




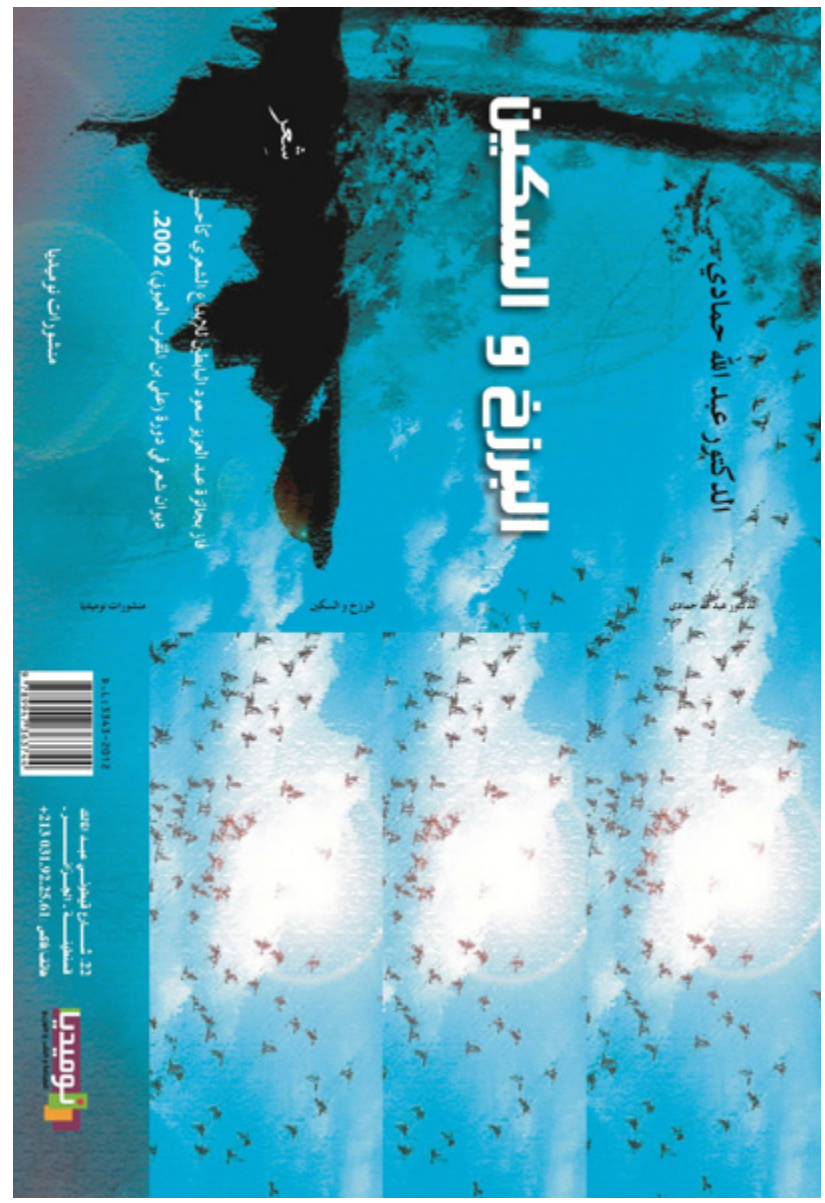




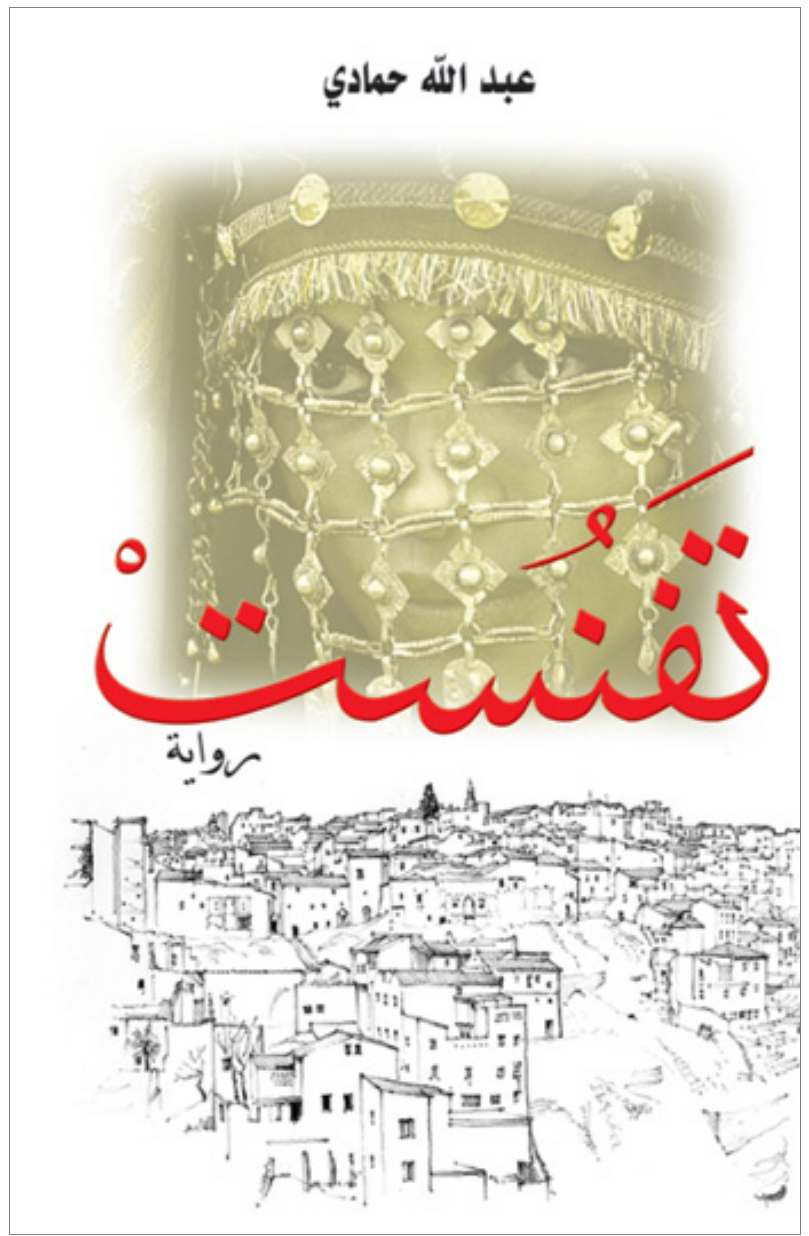




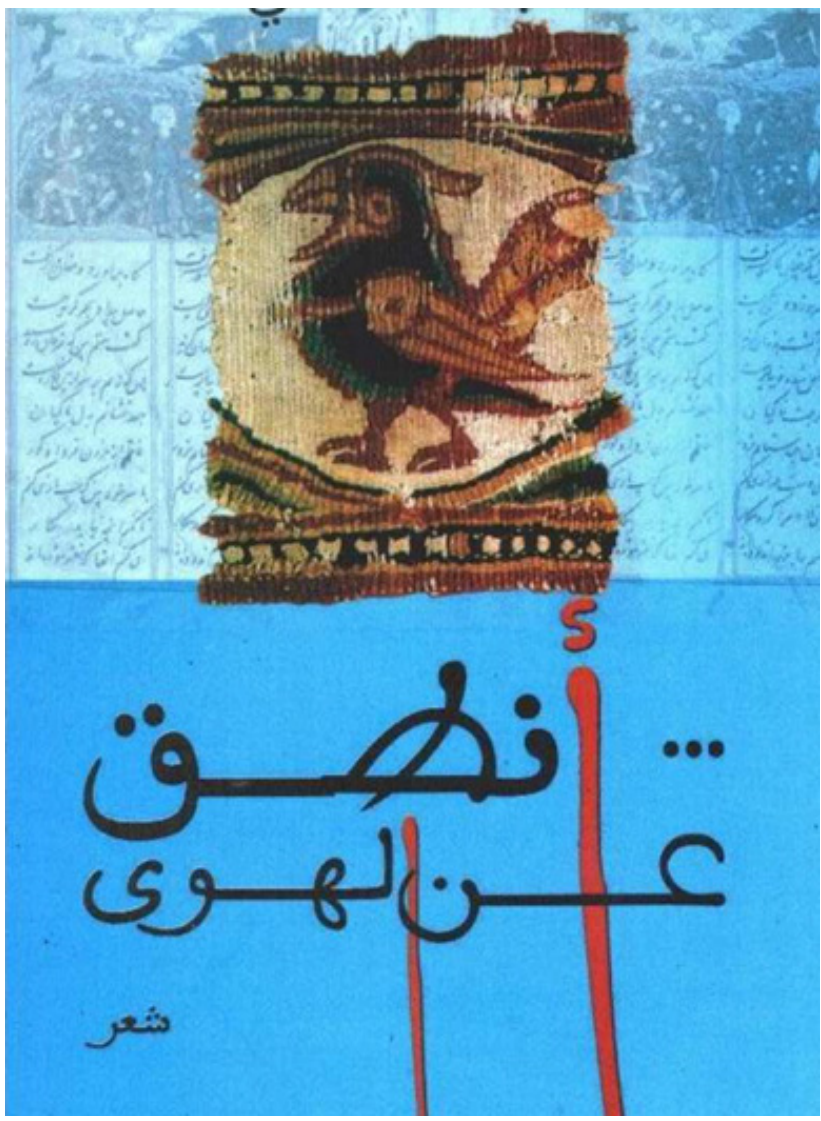




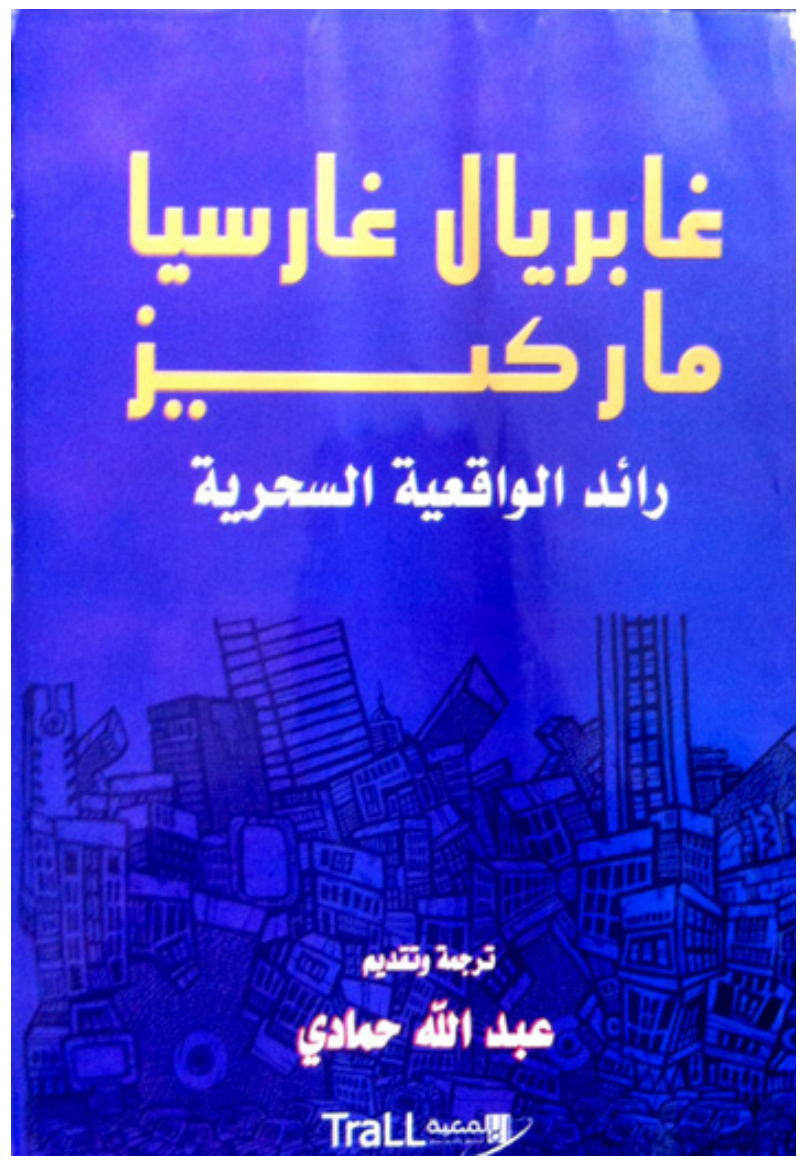




\section{عبلد الآله حمادي}

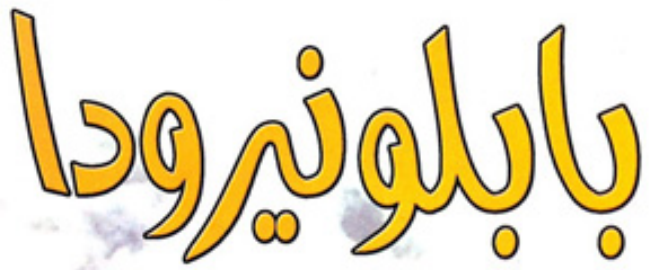

Jy

(مقارية نقيةهة)

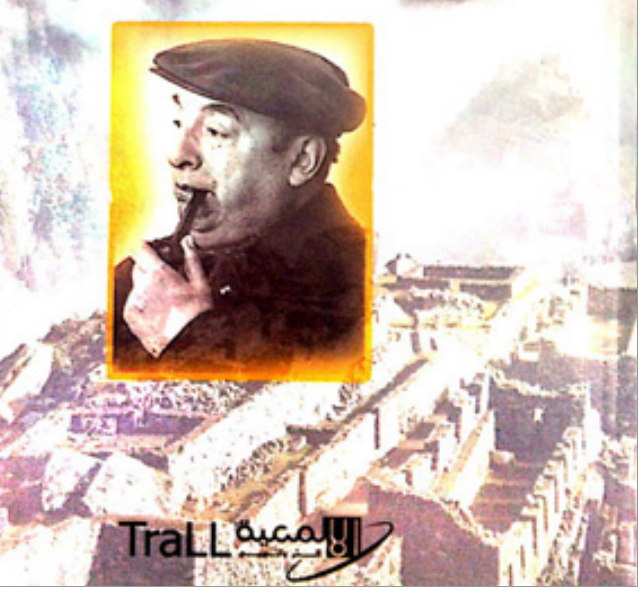




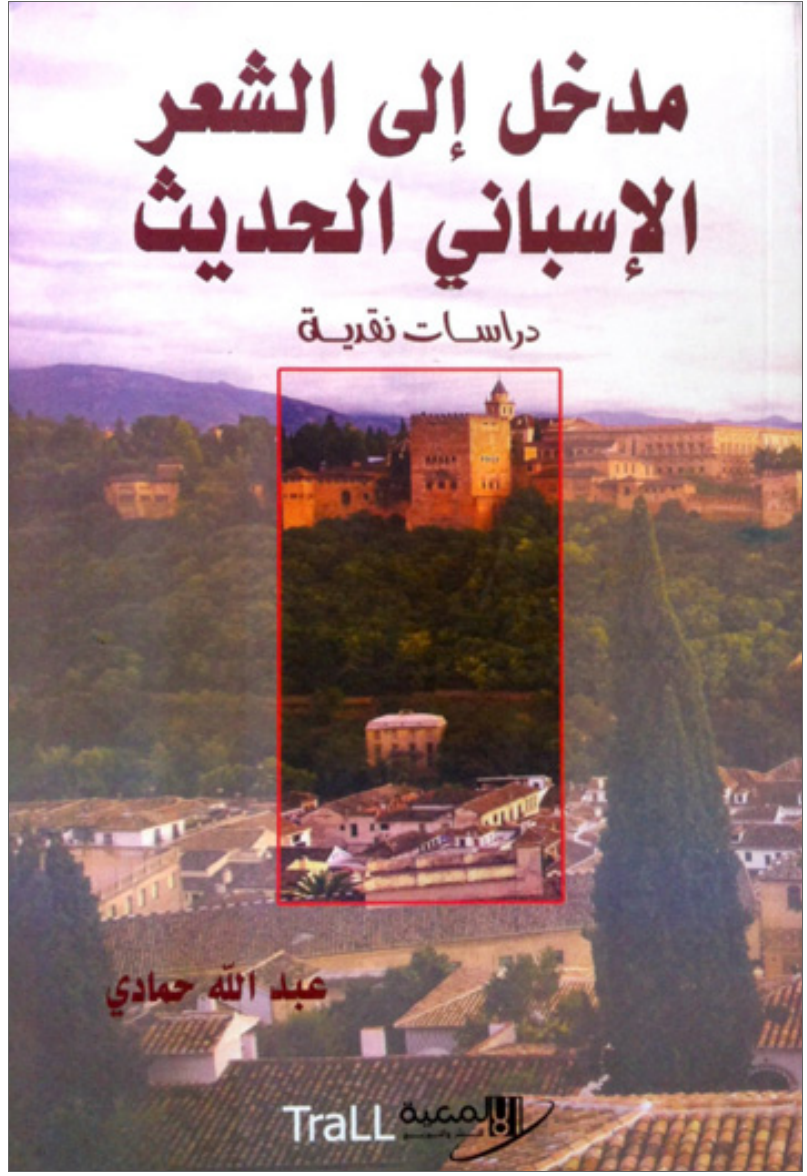




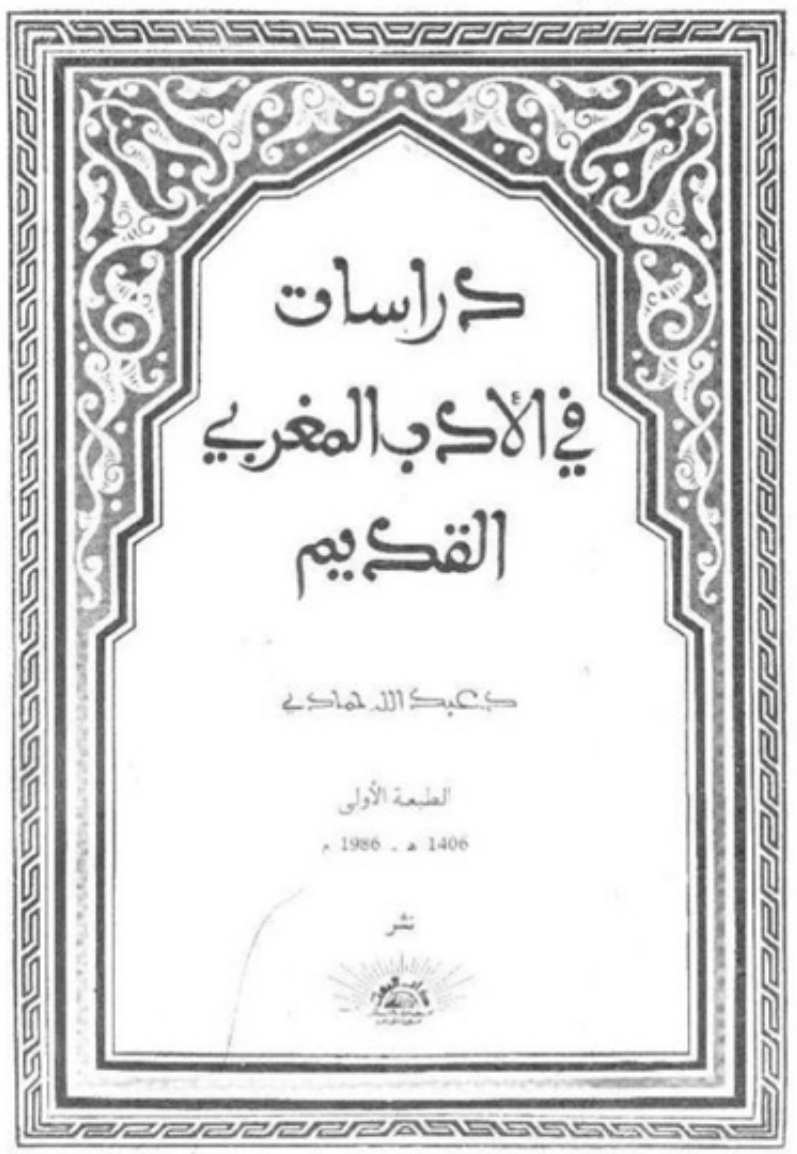



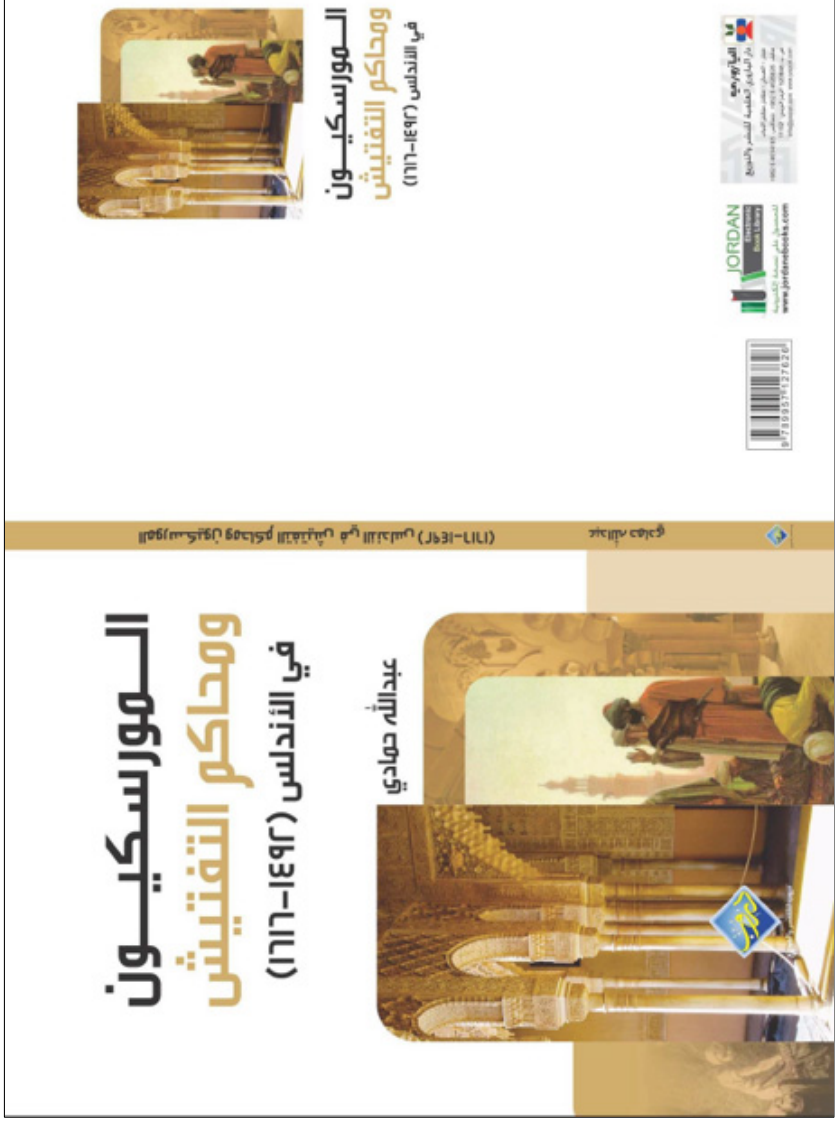


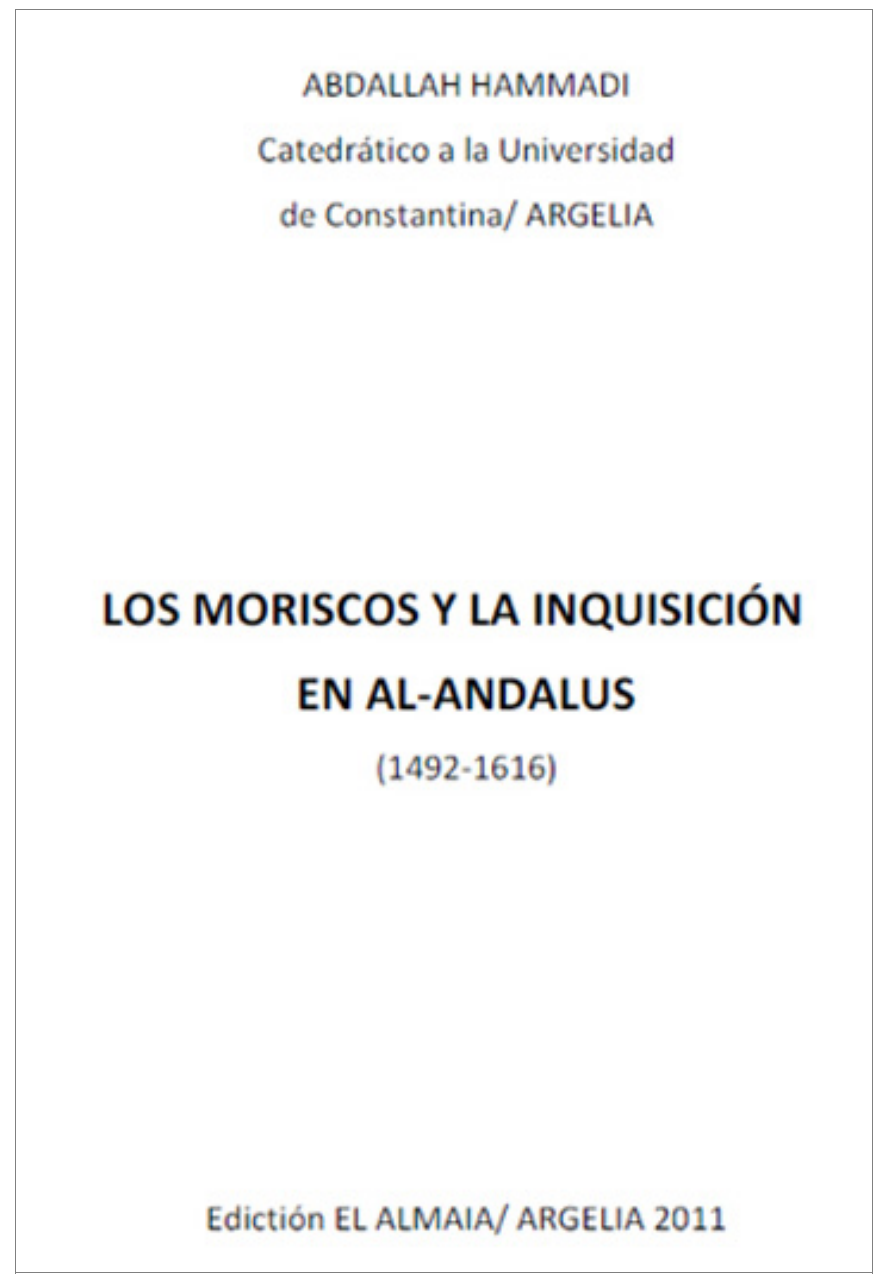




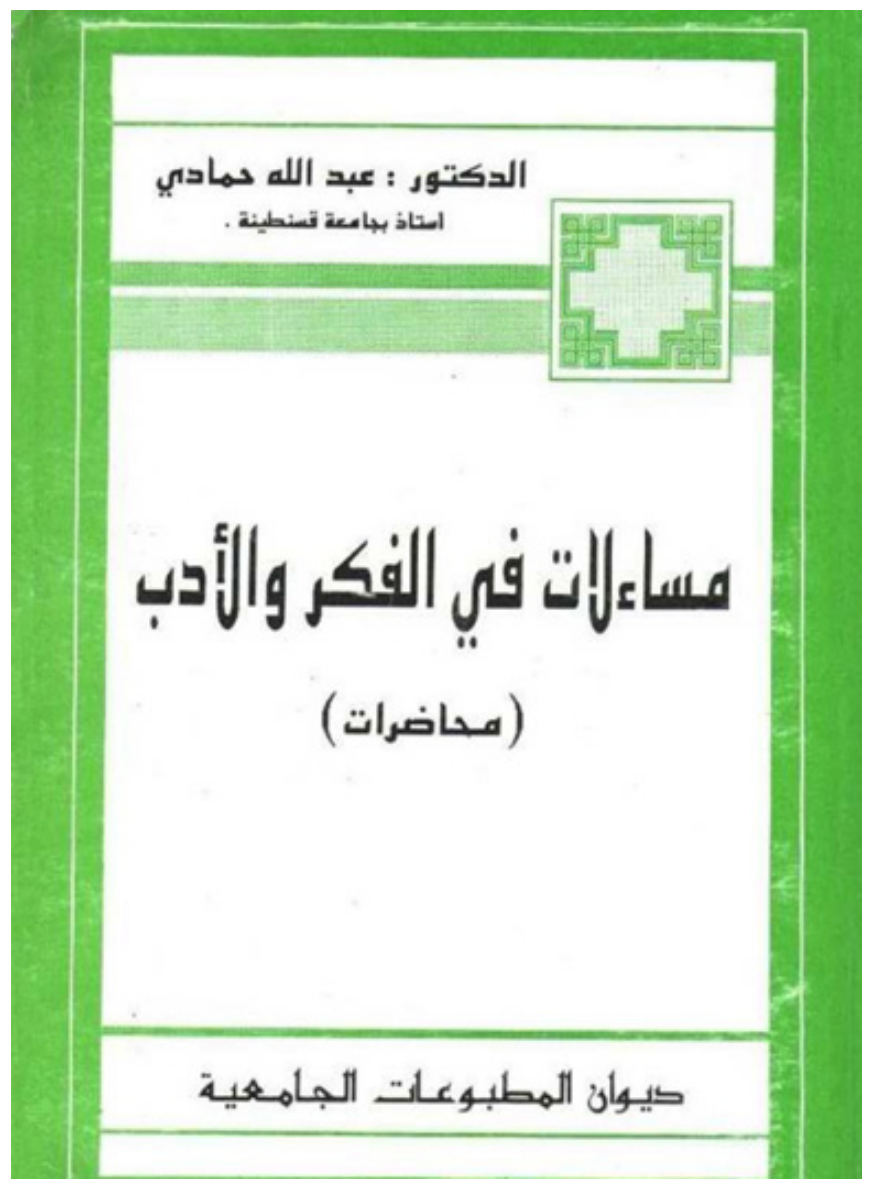




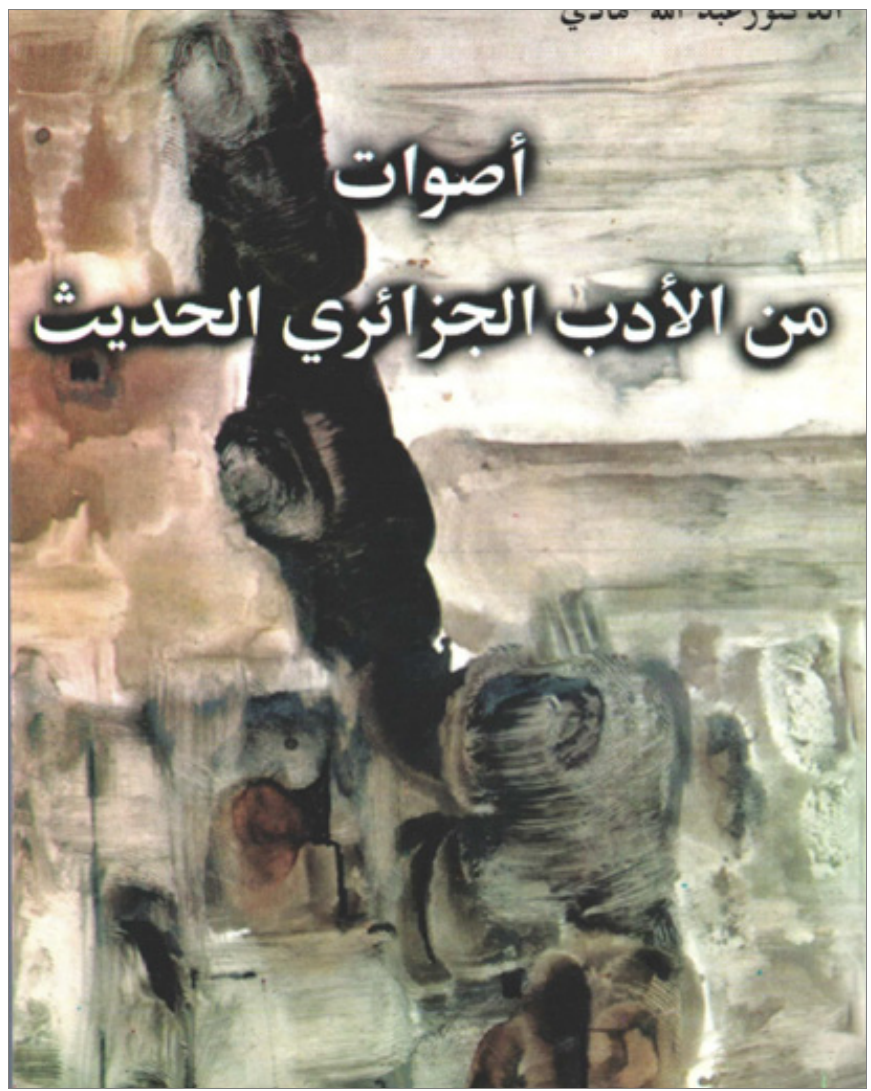




\section{כ. عبد الله هماطيى}
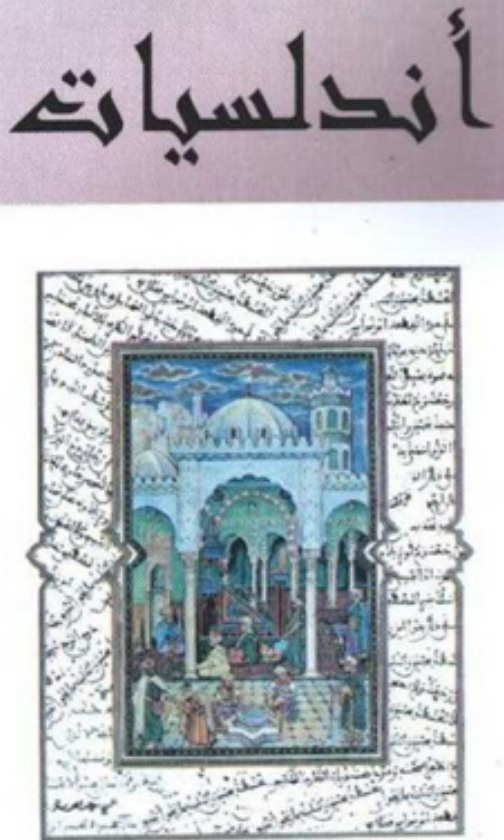


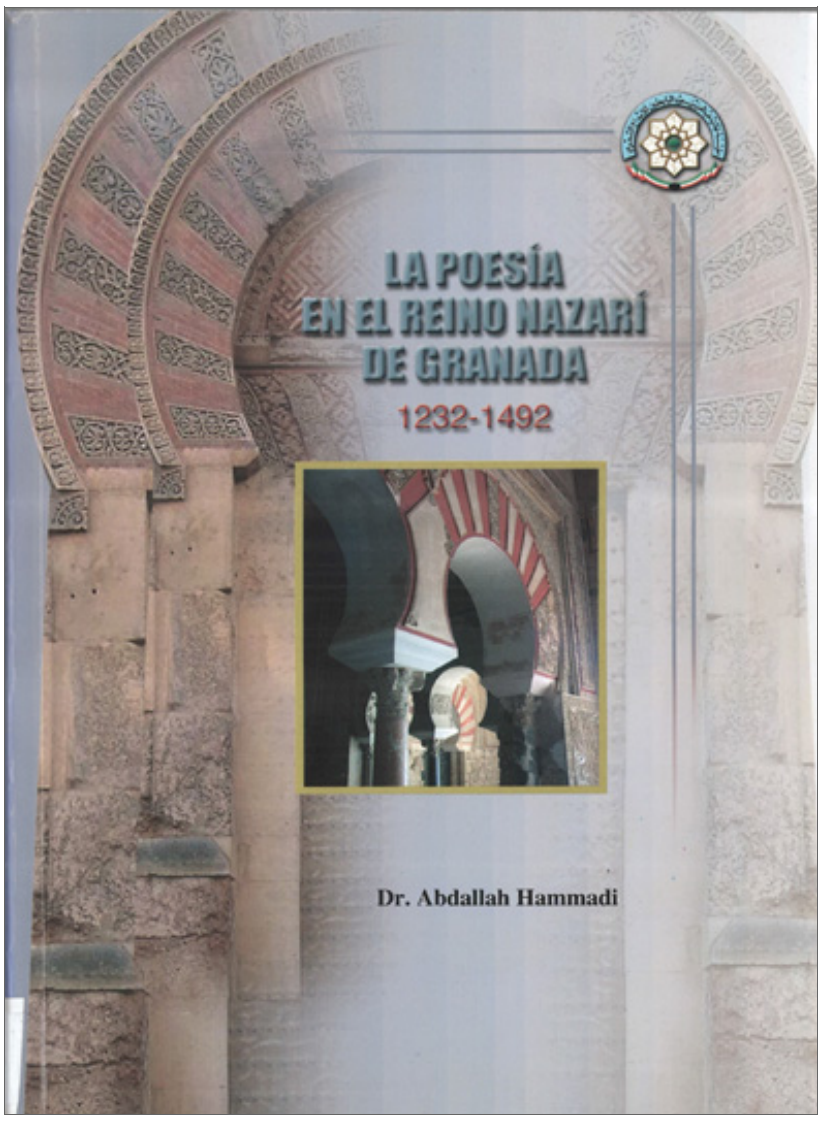




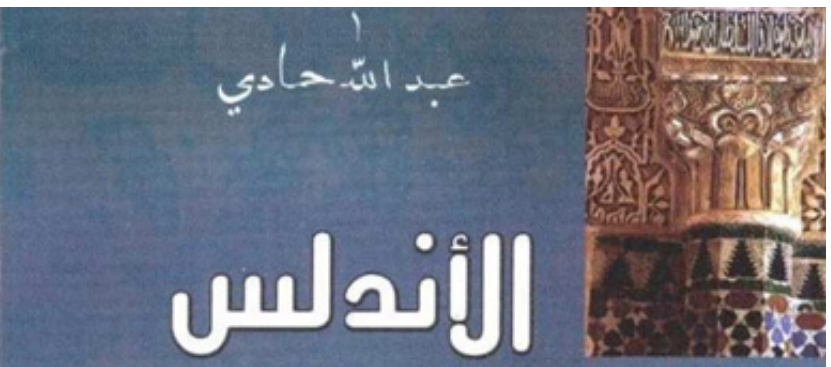
بين|لحفع والحميمة.

$$
\text { أنطولوجيا ين الشع الإسباني الأندلي العاصر }
$$

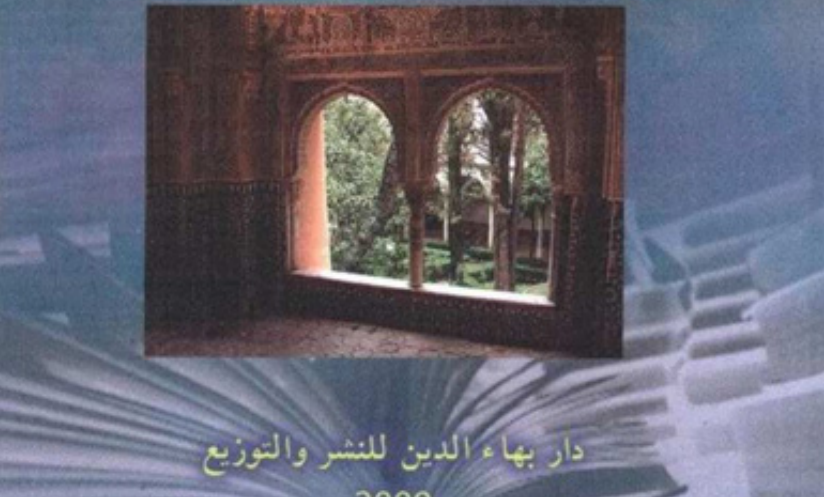




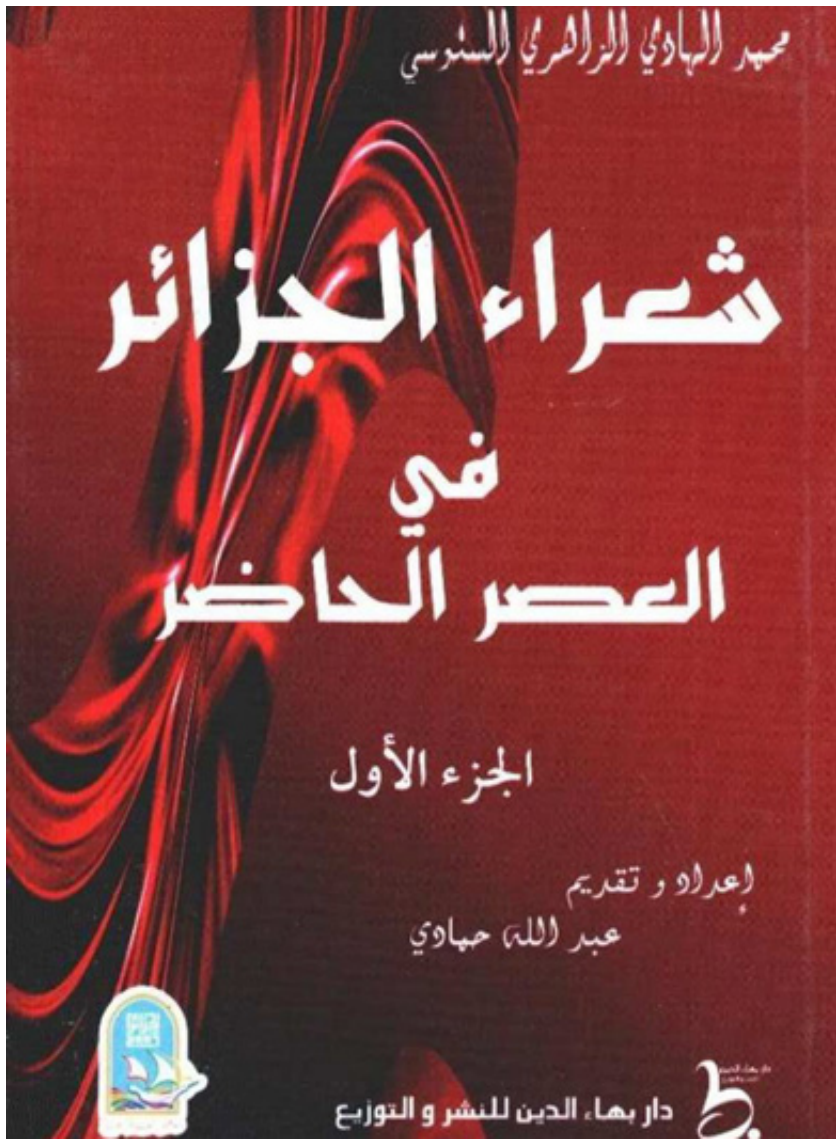



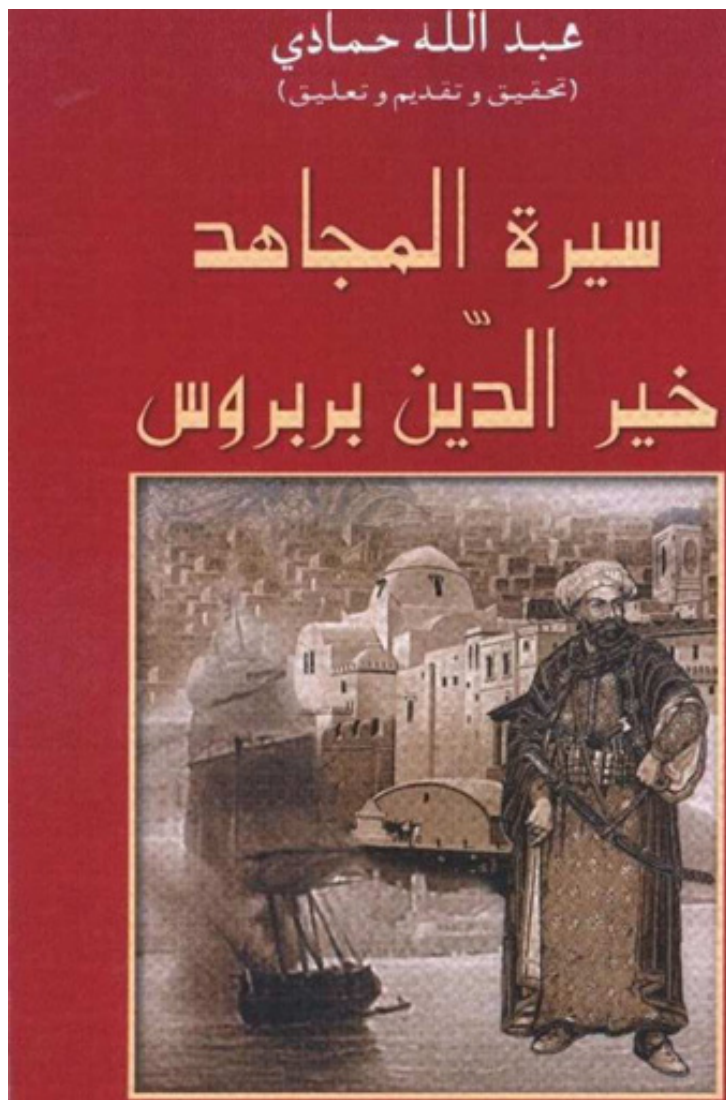


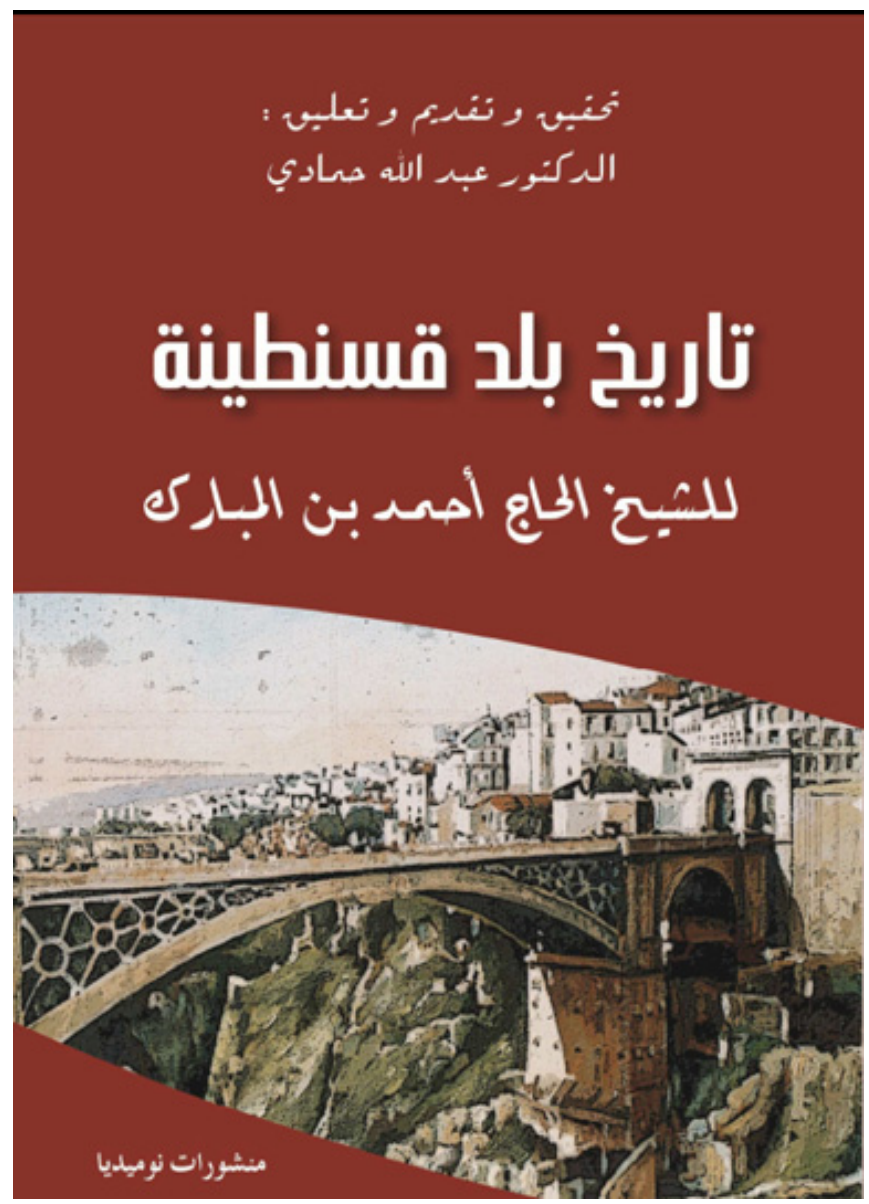




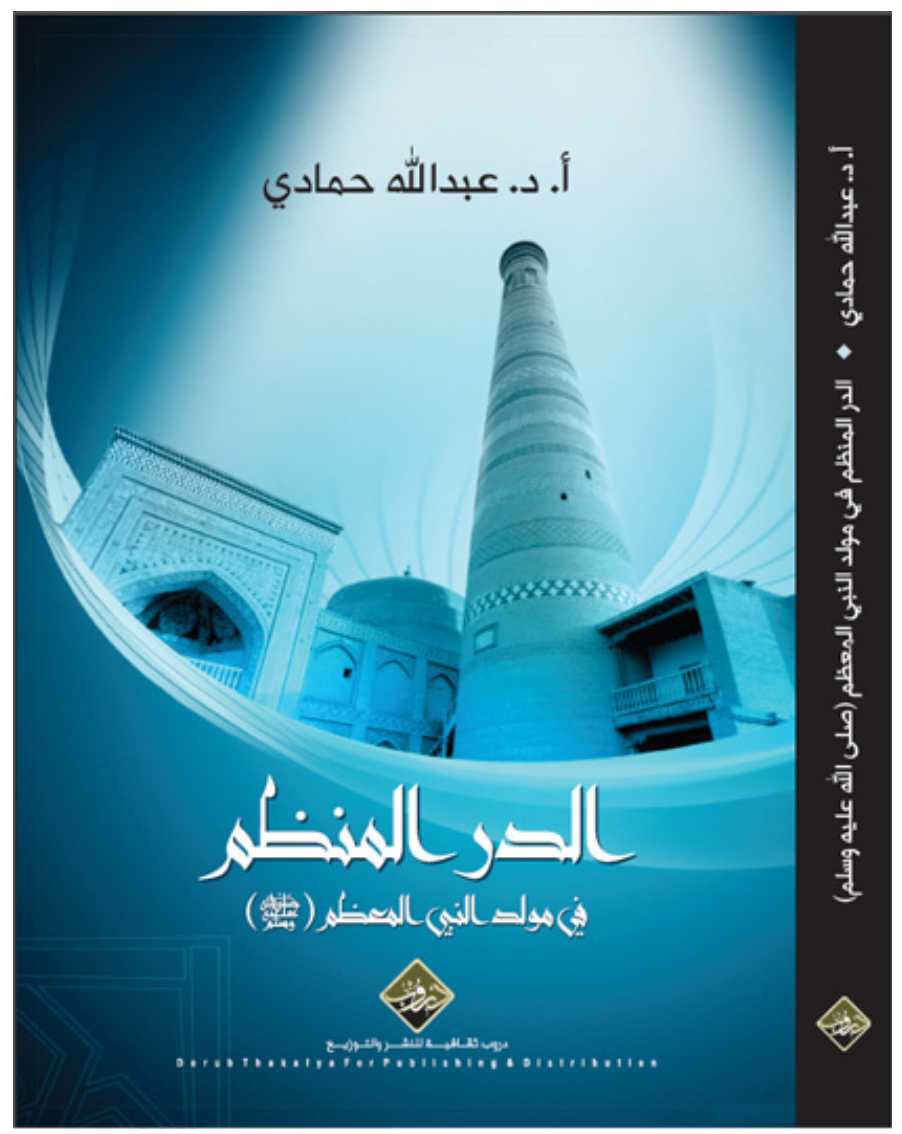

